\title{
AKTUALISASI PRINSIP HUKUM PELESTARIAN FUNGSI LINGKUNGAN HIDUP DALAM KEBIJ AKAN PERUBAHAN PERUNTUKAN, FUNGSI, DAN PENGGUNAAN KAWASAN HUTAN
}

\author{
Iskandar \\ Fakultas Hukum Universitas Bengkulu \\ E-mail: suttaniskandar@yahoo.com
}

\begin{abstract}
This article are intended to describe the thirteen principles of environment conservation law in sustainable forest management as an instrument of prevention of forest damage. In the realization, almost all of the principles are not applied or not be the basis of consideration, either by the Ministry of Forestry, relevant sector ministries, and local governments in establishing the concervation policies. This makes the implementation of policies to use, changes in the function, and use (permission to borrow to use) the forest resist of violations and irregularities. Therefore, it needs to be developed (ius constituendum perspective) the principle of environmental law as a general principles, which has the nature of force and lead to the development of leadership character of the decision makers.
\end{abstract}

Key words: Actualization, Principles of Law, Conservation, Environment Functions, Forest.

\begin{abstract}
Abstrak
Tulisan ini dimaksudkan untuk menjelaskan tentang tiga belas prinsip hukum pelestarian fungsi lingkungan hidup dalam pengelolaan kawasan hutan berkelanjutan sebagai instrumen pencegahan kerusakan kawasan hutan. Dalam realisasinya, hampir semua prinsip tidak diterapkan atau tidak dijadikan dasar pertimbangan, baik oleh Kementerian Kehutanan, kementerian sektor terkait, maupun pemerintah daerah dalam menetapkan kebijakan perubahan peruntukan, perubahan fungsi, dan penggunaan kawasan hutan. Hal ini menjadikan pelaksanaan kebijakan perubahan peruntukan, perubahan fungsi, dan penggunaan (izin pinjam pakai) kawasan hutan sarat dengan pelanggaran dan penyimpangan. Oleh karena itu, perlu dikembangkan (perspektif ius constituendum) prinsip hukum lingkungan sebagai asas umum (general principles), yang lebih memiliki sifat memaksa dan mengarah pada pembangunan karakter kepemimpinan para pengambil keputusan.
\end{abstract}

Kata kunci: Aktualisasi, Prinsip Hukum, Pelestarian, Fungsi Lingkungan, Kawasan Hutan.

\section{Pendahuluan}

Pasal 19 Undang-undang Nomor 41 Tahun 1999 tentang Kehutanan menyebutkan bahwa istilah alih fungsi adalah perubahan peruntukan dan fungsi kawasan hutan; perubahan peruntukan kawasan hutan, terjadi melalui proses tukar-menukar kawasan hutan dan pelepasan kawasan hutan. Alih fungsi kawasan hutan, yang terjadi melalui perubahan peruntukan kawasan hutan terfokus untuk mendukung kepentingan di luar kehutanan (pertanian, perkebunan, transmigrasi, pengembangan wilayah, dan non kehutanan lainnya). Alih fungsi kawasan hutan dapat pula melalui perubahan fungsi hu- tan namun tidak mengurangi luas kawasan hutan, misalnya untuk tujuan pembangunan kehutanan (konservasi kawasan hutan alam/tanaman, hutan pendidikan/ penelitian). ${ }^{1}$

\footnotetext{
Perubahan peruntukan hutan lindung dan hutan konservasi secara ilegal yang telah dijadikan areal perkebunan, pertambangan, budi daya pertanian, menjadi lahan terbuka dan semak belukar, sudah sangat mengkhawatirkan, baik di Sumatera Utara, Aceh, Kalimantan Barat, Kalimantan Tengah, Banyumas, maupun Taman Nasional Gunung Ciremai (TNGC), J awa Barat. Terus menurunnya jumlah mata air di wilayah TNGC yang semula mencapai 156 buah, kini menyusut tinggal 53 buah. Lihat dan Bandingkan dengan Edy Lisdiyono, "Penyimpangan Kebijakan Alih Fungsi Lahan Dalam Pelestarian Lingkungan Hidup", Majalah IImiah Hukum dan Dinamika Masyarakat, Fakultas Hukum
} 
Kerusakan kawasan hutan disebabkan oleh beberapa faktor. Salah satu faktor yang menarik untuk dikaji yaitu persoalan perubahan (alih) kawasan hutan. Perubahan kawasan hutan dapat berupa perubahan peruntukan yaitu dalam bentuk tukar-menukar kawasan hutan dan pelepasan kawasan hutan, untuk kepentingan perkebunan, permukiman transmigrasi, industri, perumahan, perkantoran dan sebagainya. Perubahan fungsi kawasan hutan yaitu mengubah fungsi kawasan hutan untuk kepentingan di luar bidang kehutanan. Selain itu ada bentuk lainnya yaitu penggunaan kawasan hutan yang dikenal dengan istilah izin pinjam pakai kawasan hutan.

Pada dasarnya kawasan hutan dapat di manfaatkan dengan tetap memperhatikan sifat, karakteristik, dan kerentanannya, serta tidak di benarkan mengubah suatu kawasan hutan yang memiliki fungsi perlindungan, dan harus dilakukan kajian yang mendalam serta komperhensif. Dalam pemanfaatan kawasan hutan harus disesuaikan dengan fungsi pokoknya yaitu fungsi konservasi, lindung dan produksi. Kesesuaian ketiga fungsi tersebut sangat dinamis dan yang paling penting yaitu agar dalam pemanfaatannya harus tetap sinergi. Meski secara normatif, konversi atau perubahan kawasan hutan dimaksud tidak dilarang oleh undang-undang, namun untuk menjaga kualitas lingkungan, sejauh mungkin dihindari terjadinya konversi/ perubahan terhadap hutan alam yang masih produktif, guna menghindari kerusakan kawasan hutan.

Namun, yang terjadi, kebijakan perubahan peruntukan, perubahan fungsi, dan penggunaan (izin pinjam pakai) kawasan hutan, sarat dengan pelanggaran dan penyimpangan baik yang bersifat prosedural maupun substansial, dan tidak diaktuali-sasikannya prinsip hukum pelestarian fungsi lingkungan hidup. Kebijakan demikian ini diyakini penulis menjadi salah satu faktor penyebab kerusakan kawasan hutan. Saat ini dan pada masa yang akan datang, kecenderungan terhadap tuntutan perubahan peruntukan, perubahan fungsi, dan penggunaan kawasan hutan untuk keperluan di luar fungsi

Universitas Tujuh Belas Agustus, Edisi Oktober 2004, hlm. 91-107 kehutanan akan senantiasa terjadi, seiring dengan dinamika pembangunan nasional, perubahan sosial, dan kemajuan teknologi. Kecenderungan ini, bila tidak diikuti dengan kebijakan yang baik, akan mempercepat laju kerusakan kawasan hutan di Indonesia. ${ }^{2}$

Mencermati hal tersebut, maka tulisan ini dimaksudkan untuk menjelaskan tentang aktualisasi prinsip hukum pelestarian fungsi lingkungan hidup dalam kebijakan alih peruntukan, alih fungsi dan pinjam pakai kawasan hutan dalam pengelolaan kawasan hutan berkelanjutan dan perspektif pengembangan prinsip hukum pelestarian fungsi lingkungan hidup sebagai asas umum dalam kebijakan pengeloIaan kawasan hutan berkelanjutan di Indonesia.

\section{Pembahasan}

\section{Aktualisasi Prinsip Hukum Pelestarian Fungsi Lingkungan Hidup Sebagai Instrumen Pence- gahan Kerusakan Kawasan Hutan Dalam Kebi- jakan Perubahan Peruntukan, Fungsi, dan Penggunaan Kawasan Hutan}

Pada hakekatnya, pengelolaan dan atau konservasi sumber daya alam bukan hanya berarti pelestarian dan perlindungan semata, akan tetapi juga pemanfaatannya secara bijaksana sesuai dengan prinsip/asas dan norma hukum yang berlaku. ${ }^{3}$ Berdasarkan hasil kajian terhadap prinsip hukum pelestarian fungsi lingkungan hidup yang diaktualisasikan dalam berbagai ketentuan terkait dengan pengelolaan sumber daya alam dan lingkungan hidup, dapat diidentifikasi sebanyak 24 prinsip hukum pelestarian fungsi lingkungan hidup. ${ }^{4} \mathrm{Di}$ antaranya terdapat 13 prinsip yang sangat relevan dijadikan pertimbangan dalam kebijakan perubahan peruntukan, fungsi, dan penggunaan kawasan hutan,

\footnotetext{
2 Yusdirman Yusuf, "Hukum Lingkungan Versus Pembangunan Nasional", Jurnal Respublica, Fakultas Hukum Universitas Lancang Kuning Pekanbaru, Vol. 4 (1), 2004, hlm. 97

3 Lihat August P Silaen, "Pelestarian Fungsi Hutan dan Lingkungan Hidup Dalam perspektif Hukum Lingkungan", Majalah IImiah Visi Universitas HKBP Nomenssen Medan, Vol. 16 (3), 2008, hlm. 575-594

4 Lihat Iskandar, 2011, Perubahan Peruntukan, Fungsi, dan Penggunaan Kawasan Hutan Ditinjau Dari Prinsip Hukum Pelestarian Fungsi Lingkungan Hidup Dalam Pengelolaan Kawasan Hutan Berkelanjutan, Bandung: Disertasi, Unpad., hlm. 111.
} 
agar dapat dicegah terjadinya kerusakan kawasan hutan. ${ }^{5}$ Prinsip dimaksud di antaranya: prinsip keadilan; prinsip akses pada informasi; prinsip partisipasi publik; prinsip kehati-hatian; prinsip perlindungan keanekaragaman hayati; prinsip tindakan pencegahan; prinsip internalisasi biaya lingkungan; prinsip daya dukung lingkungan; prinsip keutuhan; prinsip keterpaduan; prinsip keseimbangan; prinsip jaminan kepastian hukum atas status kawasan hutan; prinsip penanggulangan dan penegakan hukum, baik preventif maupun represif secara tegas dan konsisten.

Berdasarkan hasil kajian terhadap aktualisasi prinsip hukum pelestarian fungsi lingkungan hidup dimaksud, pada kenyataannya belum sepenuhnya diaktualisasikan dalam kebijakan perubahan peruntukan, fungsi, dan penggunaan kawasan hutan. Berbagai bentuk perizinan terkait dengan kebijakan peruntukan, fungsi, dan penggunaan kawasan hutan yang diberikan kepada perusahaan besar, pada sektor perkebunan dan pertambangan, ${ }^{6}$ serta kebijakan perubahan kawasan untuk kepentingan sektor transmigrasi, belum menerapkan prinsip pelestarian fungsi lingkungan hidup, karena faktanya masih banyak penyimpangan dan pelanggaran yang terjadi, baik dilihat dari aspek kewenangan, prosedur maupun substansinya.

Prinsip hukum pelestarian fungsi lingkungan hidup dimaksud seharusnya dapat menjadi instrumen dalam rangka pencegahan kerusakan kawasan hutan, apabila para pengambil keputusan taat asas dan konsisten menerapkan

\footnotetext{
5 lbid., hlm. 241.

6 Seperti di antaranya: PT. Freeport Indonesia di Papua, PT. Karimun Granit di Kepulauan Riau, PT. Inco Tbk di Sulawesi Selatan, Sulawesi Tengah, Sulawesi Tenggara, PT. Arutmin Indonesia dan PT. Indocement Tunggal Perkasa (ITP) Tbk., di Kalimantan Selatan, PT. Indominco Mandiri di Kalimantan Timur, PT. Aneka Tambang di Maluku Utara, PT. Natarang Mining di Maluku Utara dan PT. Nusa Halmahera Minerals di Maluku Utara. Perusahaan Iainnya, yaitu PT. Kalimantan Surya Kencana, PT. Asmin Koalindo Tuhup, PT. Pelsart Tambang Kencana di Kalimantan Selatan, PT. Interex Sacra Raya di Kalimantan Timur dan Kalimantan Selatan, PT. Weda Bay Nickel di Maluku Utara, PT. Gag Nikel di Papua, PT. Sorik-mas Mining di Sumaterra Utara, PT. Aneka Tambang di Sulawesi Tenggara, PT Riau Andalan Pulp and Paper (RAPP) dan PT Indah Kiat Pulp and Paper (IKPP) di Riau, dan masih banyak lagi perusahan besar lainnya, lihat ibid., hlm. 249.
}

prinsip dimaksud sebagai acuan dalam penetapan kebijakan dan atau pengambilan keputusannya. Berikut ini diuraikan secara ringkas implementasi dari 13 (tiga belas) prinsip dimaksud. ${ }^{7}$

\section{Prinsip Keadilan (The Principles of J ustice)}

Prinsip keadilan mengandung makna bahwa dalam menetapkan kebijakan perubahan peruntukan, fungsi, dan penggunaan kawasan hutan harus memperhatikan aspek keadilan, baik keadilan untuk generasi saat ini maupun keadilan pada generasi yang akan datang, termasuk di dalamnya keadilan secara ekonomi, sosial dan lingkungan hidup. Pada kenyataannya, dari hasil kajian terhadap kebijakan perubahan peruntukan, fungsi, dan penggunaan kawasan hutan yang dilakukan selama ini, belum menerapkan prinsip keadilan, baik oleh para pengambil keputusan di tingkat pusat mau pun di daerah. ${ }^{8}$ Keadilan dimaksud, baik secara ekonomi, sosial maupun keadilan bagi lingkungan hidup. ${ }^{9}$ Hal ini terlihat dalam kebijakan perubahan peruntukan, fungsi, dan penggunaan dimaksud yang secara ekonomi hanya menguntungkan pihak pengusaha atau perusahaan yang memiliki modal besar, terutama di sektor perkebunan dan pertambangan. Sasaran kebijakan ini tidak menyentuh kepentingan ekonomi masyarakat, terutama masyarakat yang berada di dalam dan di sekitar kawasan hutan yang di alih fungsikan, sehingga masyarakat merasakan ada ketidakadilan dalam pemanfaatan ekonomi dari kawasan hutan yang berada di sekitar atau di wilayah tempat tinggalnya.

Kebijakan perubahan peruntukan, fungsi, dan penggunaan kawasan hutan yang diberikan

\footnotetext{
Ibid., hlm 294.

8 Bandingkan dengan Dade Angga, "Kemitraan Pemerintah, Masyarakat Dan Swasta Dalam Pembangunan: Suatu Studi Tentang Kasus Kemitraan Sektor Kehutanan Di Kabupaten Pasuruan, J urnal Aplikasi Manajemen Jurusan Manajemen Universitas Brawijaya, Vol. 4 (3), 2006, hlm. 395402; Lihat Ridwan, "Memunculkan Karakter Hukum Progresif Dari Asas-Asas Umum Pemerintahan Yang Baik Solusi Pencarian dan Penemuan Keadilan Substantive", Jurnal Hukum Pro Justitia, Program Studi IImu Hukum Universitas Katholik Parahyangan, Vol. 26 (2), 2008, hlm. 163-177

9 Abdul Bari Ts, "Keanekaragaman Hayati Dalam Pembangunan", Duta Rimba: Majalah Bulanan Perum Perhutani J akarta, Vol/ 2 (197-198), 1996, hlm. 19-20;
} 
kepada perusahaan besar berimplikasi pada tidak terjamin pemerataan kesempatan berusaha yang berkeadilan. Penguasaan lahan perkebunan pada kelompok usaha besar, dikhawatirkan menimbulkan kontra produktif dengan tujuan pertumbuhan ekonomi yang berkeadilan yang hendak dicapai, terutama dalam usaha menumbuhkan usaha perkebunan dan pertambangan rakyat. Hal ini karena pemegang hak guna usaha (HGU) perkebunan dan kuasa pertambangan besar kurang memiliki insentif untuk mengelola arealnya secara efisien dan lestari, sehingga menyebabkan sebagian besar sumber daya lahan menjadi tidak termanfaatkan secara optimal. Kondisi di lapangan memperlihatkan bahwa ada kecenderungan pengusaha menelantarkan lahan yang telah mendapatkan izin.

Kebijakan perubahan peruntukan, fungsi, dan penggunaan kawasan hutan, yang seharusnya lebih mengutamakan fungsi lindung dan fungsi konservasi dengan cara memperluas luasan kawasan lindung dan kawasan konservasi atau paling tidak mempertahankan keberadaan fungsi lindung, fungsi perlindungan setempat, dan fungsi penyangga kehidupan pada masingmasing kawasan hutan, akan tetapi yang terjadi justru kebijakan perubahan fungsi yang terjadi lebih banyak dalam bentuk penurunan status dari kawasan lindung atau konservasi menjadi kawasan budi daya, sehingga tahap berikutnya dapat dilakukan perubahan peruntukan, apakah melalui tukar-menukar atau melalui pelepasan kawasan hutan. ${ }^{\mathbf{1 0}}$

Meski perubahan peruntukan, fungsi, dan penggunaan kawasan hutan dilakukan untuk memenuhi tuntutan dinamika pembangunan

\footnotetext{
10 Perubahan peruntukan kawasan hutan dengan cara tukarmenukar kawasan dalam pelaksanaannya selain terdapat penyimpangan atau pelanggaran terhadap ketentuan yang bersifat substantive, juga mengenyampingkan prinsip hukum pelestarian fungsi lingkungan hidup terhadap keberadaan kawasan Taman Nasional, kawasan Cagar Alam yang seharusnya dipertahankan. Prosedur penetapan kebijakan tanpa melalui kajian yang mendalam terutama dari aspek lingkungan hidup, dengan mudahnya dilakukan perubahan fungsi kawasan, dari kawasan Taman Nasional dan atau kawasan Cagar Alam diubah menjadi kawasan Hutan Produksi (HPT/HPK), Ialu kemudian dapat dimanfaatkan sesuai dengan kepentingan yang dikehendaki, dengan cara pelepasan kawasan hutan dan atau tukar-menukar kawasan hutan, lihat: Ibid., hlm 249.
}

nasional dengan berlandaskan pada optimalisasi distribusi fungsi, namun keadilan bagi kepentingan masyarakat dan keadilan bagi kelestarian lingkungan hidup, harus tetap dikedepankan, sehingga manfaat kawasan hutan dapat berkelanjutan, karena keberadaan kawasan hutan dengan luasan yang cukup dan sebaran yang proporsional tetap terjaga. Dengan demikian kebijakan perubahan peruntukan, fungsi, dan penggunaan kawasan hutan dapat mencerminkan keadilan baik untuk generasi saat ini maupun generasi yang akan datang.

\section{Prinsip Akses pada Informasi (The Principles of Access to Information)}

Data yang penulis peroleh dari Kementerian Kehutanan, menurut penulis belum merupakan data yang riil atau data yang sesungguhnya. Hal ini terbukti dari jumlah luas kawasan hutan yang tidak pernah ditemukan angka yang sama pada setiap kali proses penetapannya. Lemahnya data dan informasi kehutanan ini tidak hanya menyangkut luas kawasan hutan, tapi juga menyangut banyak aspek dari kehutanan. Dengan melihat kenyataan ini, Menteri Kehutanan memandang perlu meminta bantuan kepada gubernur di seluruh Indonesia, dengan mengeluarkan kebijakan dekonsentrasi melalui Peraturan Menteri Kehutanan Republik Indonesia Nomor: P. 7/ Menhut-II/2010, tanggal $26 \mathrm{~J} \mathrm{a-}$ nuari 2010, Tentang Pelimpahan Sebagian Urusan Pemerintahan (dekonsentrasi) Bidang Kehutanan Tahun 2010 Kepada 33 Gubernur Pemerintah Provinsi Selaku Wakil Pemerintah. ${ }^{11}$

Selain pelimpahan wewenang kepada 33 gubernur yang sebagian besar terkait dengan urusan pendataan bidang kehutanan, pada tanggal 25 Pebruari 2010, Menteri Kehutanan meminta para gubernur (kepala daerah) seluruh Indonesia menyampaikan laporan penggunaan kawasan hutan untuk kegiatan nonkehutanan di wilayah masing-masing. Surat Edaran Menteri

\footnotetext{
${ }^{11}$ Sebagai salah satu contoh, penulis kemukakan urusan pemerintahan di bidang kehutanan yang dilimpahkan kepada Gubernur Riau. Urusan yang dilimpahkan kepada Gubernur Riau merupakan urusan yang paling banyak di bandingkan dengan 32 gubernur lainnya, yaitu sebanyak 34 urusan pemerintahan. Lihat lebih lengkap pada Peraturan Menteri Kehutanan tersebut di atas.
} 
Kehutanan disampaikan kepada sebanyak 26 gubernur, yang diberi waktu dua bulan untuk menginventarisir berapa luas kawasan hutan yang sudah digunakan untuk kebun/tambang atau kegiatan lain, tanpa izin pelepasan kawasan dari Kementerian Kehutanan. ${ }^{12}$

Menteri Kehutanan dalam surat edarannya, meminta gubernur menginventarisir data penggunaan kawasan hutan untuk kepentingan nonkehutanan, seperti kebun sawit, tambang, tambak, pembangunan sarana prasarana (perumahan dan lain lain), dan penerbitan sertifikat, termasuk penerbitan HGU pada kawasan hutan tanpa izin dari Menteri Kehutanan. Dalam waktu dua bulan, hasil inventarisir kawasan dan langkah penegakan hukum yang sudah diambil di daerah itu harus disampaikan kepada Menteri Kehutanan dengan tembusan kepada Ketua KPK, J aksa Agung, Kapolri, dan Menteri Negara Lingkungan Hidup. ${ }^{13}$ Namun, sampai dengan buIan Mei 2010 pada saat penulis melakukan penelitian, laporan dari para gubernur dimaksud belum ada, sehingga belum dapat diketahui data/ informasi sebagaimana maksud dikeluarkannya surat edaran Menteri Kehutanan.

Prinsip akses informasi bagi masyarakat atas kebijakan perubahan peruntukan, fungsi, dan penggunaan kawasan hutan merupakan persoalan fundamental yang harus dibenahi, agar masyarakat pada umumnya dan masyarakat yang berada di dalam dan di sekitar kawasan hutan dimaksud, dapat turut berperan aktif dalam pengelolaan kawasan hutan. ${ }^{14}$ Se-

\footnotetext{
${ }^{12}$ Surat Edaran Menteri Kehutanan Nomor: S. 95/MenhutIV/ 2010, tanggal 25 Pebruari 2010.

${ }^{13}$ Sebelumnya, Menteri Kehutanan, sudah terlebih dahulu melakukan upaya penertiban penggunaan kawasan hutan yang tak prosedural, dengan melakukan investigasi dan operasi penertiban reguler di Sumatera, Riau, dan Kalimantan. Di Sumatera Utara di temukan 16 perusahaan yang melanggar ketentuan Undang-undang Nomor: 41 Tahun 1999 tentang Kehutanan. Berdasarkan hasil investigasi di Kalimantan Tengah, Kementerian Kehutanan menginventarisir terdapat 960.000 ha kawasan hutan yang diubah peruntukannnya untuk usaha nonkehutanan tanpa izin pelepasan, tukar- menukar ataupun izin pinjam pakai kawasan hutan dari Menteri Kahutanan. Selain itu di Kalimantan Timur sudah diketahui sebanyak 150 perusahaan melakukan perambahan kawasan.

${ }^{14}$ Lihat Masduki, "Masyarakat Terbuka Dan Kebebasan Mengakses Informasi, Agenda Pemberdayaan Masyarakat Sipil Rezim SBY-Kalla", Majalah IImiah Unisia, Universitas Islam Indonesia Yogyakarta, Vol. 28 (55), 2005, hlm. 60-70
}

lain akses atas informasi, juga akses masyarakat terhadap pemanfaatan kawasan hutan harus diatur tidak hanya yang berkaitan dengan pemanfaatan hutan hak tetapi juga akses masyarakat terhadap pemanfaatan kawasan hutan (hutan negara).

Penulis berharap prinsip akses terhadap informasi khususnya terkait dengan kebijakan perubahan kawasan hutan, akan dapat terwujud dan diterapkan, sehingga data dan informasi dapat dengan mudah diakses oleh masyarakat dan pihak yang berkepentingan, khususnya kebijakan perubahan kawasan hutan. Terlebih lagi setelah dikeluarkannya Peraturan Menteri Kehutanan Republik Indonesia Nomor: P.02/ Menhut-II/ 2010 Tentang Sistem Informasi Kehutanan. Dalam Pasal 5 peratuan Menteri Kehutanan ini disebutkan bahwa penyelenggaraan sistem informasi kehutanan meliputi berbagai jenis data dan informasi kehutanan. Data kawasan dan potensi hutan antara lain meliputi: luas kawasan hutan dan perairan; tata batas kawasan hutan; luas kawasan hutan yang telah ditetapkan; luas dan letak perubahan fungsi dan peruntukan kawasan hutan; luas dan letak kesatuan pengelolaan hutan; potensi hasil hutan kayu; potensi hasil hutan bukan kayu; luas areal yang tertutup dan tidak tertutup hutan; luas dan letak areal penggunaan kawasan hutan; jenis flora dan fauna yang dilindungi; gangguan keamanan hutan; lokasi dan luas areal kebakaran hutan; dan perlindungan hutan.

\section{Prinsip Partisipasi Publik (The Principles of Public Participation)}

Terkait dengan kebijakan perubahan peruntukan, fungsi, dan penggunaan kawasan hutan, prinsip partisipasi publik juga belum di terapkan dengan baik. Hal ini terbukti dari tidak adanya akses atas informasi dalam kebijakan perubahan kawasan hutan. Dengan tidak adanya akses informasi, maka dengan sendirinya masyarakat dan pihak yang berkepentingan tidak dapat mengetahui berbagai kebijakan yang akan ditetapkan, termasuk dalam kebijakan penetapan perubahan kawasan hutan. Padahal partisipasi seluruh pemangku kepen- 
tingan dalam proses perencanaan dan pengambilan keputusan sangatlah urgen. ${ }^{15}$

Terdapat beberapa aktor atau pihak yang berkepentingan yang dapat terlibat, jika menginginkan pengelolaan kawasan hutan secara berkelanjutan. Pihak tersebut yaitu masyarakat lokal dan institusinya, birokrat dan birokrasi pemerintahannya, pengusaha dan perusahaannya, ilmuwan atau para ahli dan lembaganya (perguruan tinggi) dan kalangan LSM (Lembaga Swadaya Masyarakat) yang memiliki perhatian pada persoalan ini. Jika sebuah kebijakan dapat melibatkan lebih banyak pihak yang berkepentingan baik dalam perumusan kebijakan maupun penerapannya, maka kebijakan atau keputusan tersebut dapat diterima oleh semua pihak, dan mampu mengakomodasikan berbagai kepentingan yang ada.

Kementerian Kehutanan dan pemerintahan di daerah yang memiliki fungsi pelayanan publik dan berperan dominan dalam pengambilan keputusan pengelolaan kawasan hutan harus dapat menempatkan pada posisi netral di antara berbagai kepentingan yang ada. Pemerintah tidak diperbolehkan sebagai alat untuk mencapai tujuan dari kelompok kepentingan tertentu, melainkan diabdikan bagi kebaikan publik, khususnya dalam menjalankan misi menyejahterakan rakyat. Dalam konteks ini, Kementerian Kehutanan dan pemerintahan di daerah merupakan alat untuk memperjuangkan kepentingan, tetapi kepentingan itu merupakan kepentingan bersama dari kelompok kepentingan yang ada secara adil. Perlu dihindari dalam mencapai tujuan pengembangan usaha perkebunan dan atau pertambangan atau usaha lainnya dengan memanfaatkan kawasan hutan merupakan satu kelompok kepentingan yang mendominasi, sehingga berakibat merugikan kelompok kepentingan lainnya.

\section{Prinsip Kehati-hatian (The Precautionary Principles)}

\footnotetext{
${ }^{15}$ J enny Ratna Suminar, "Komunikasi dan Perluasan Partisipasi Publik Dalam Pembangunan", Governance: Sinergi Masyarakat, Swasta dan Pemerintah Yang Berkeadilan, Pusat Penelitian Kebijakan Publik Dan Pengembangan Wilayah Universitas Padjadjaran, Vol. 3 (9) tahun 2007, hlm. 15
}

Pada kenyataannya prinsip kehati-hatian ini juga belum sepenuhnya diterapkan dalam kebijakan perubahan peruntukan, fungsi, dan penggunaan kawasan hutan. Dalam banyak kasus perubahan peruntukan, fungsi, dan penggunaan kawasan hutan, telah diterbitkan berbagai izin tanpa diikuti dengan persyaratan yang ditentukan oleh peraturan perundang-undangan terkait. Misalnya kewajiban untuk menyusun AMDAL, adanya kajian oleh Tim Terpa$\mathrm{du}$, adanya rekomendasi sebagai bentuk persetujuan dari DPR. Demikian juga kewajiban untuk menyediakan areal sebagai pengganti kawasan yang dilakukan alih fungsi. Persyaratan dan kewajiban belum dipenuhi, akan tetapi izin telah dikeluarkan, dan yang lebih memprihatinkan lagi, bahkan izin dari Menteri Kehutanan belum dikeluarkan namun kawasan hutan sudah dimanfaatkan untuk berbagai kepentingan.

Belum diterapkannya prinsip kehati-hatian juga terlihat dari kebijakan atau keputusan izin dan atau persetujuan prinsip telah dikeluarkan oleh Kementerian Kehutanan, HGU oleh BPN, izin lokasi oleh pemerintah daerah. Kebijakan atau keputusan dikeluarkan dengan tidak mempertimbangkan fungsi lindung, fungsi perlindungan setempat, fungsi penyangga kehidupan, fungsi perlindungan keanekaragaman hayati dari kawasan hutan tertentu yang dimohonkan untuk dilepas, ditukar, diubah fungsi dan atau diberi izin pinjam pakai untuk berbagai kepentingan. Tidak dipertimbangkannya fungsi tersebut karena keputusan ditetapkan tanpa didasarkan data yang lengkap, akurat dan kondisi riil dari suatu kawasan hutan yang dimohon tersebut. Selain itu, keputusan diambil hanya didasarkan atas informasi sepihak dari pemohon, tanpa diikuti pemeriksaan fisik di lapangan. Apabila demikian faktanya, maka dapat diperkirakan apa yang akan terjadi dengan keberlanjutan kawasan hutan dengan segala dampak negatifnya.

\section{Prinsip Perlindungan Keanekaragaman Hayati (Biodiversity Concervation Principles)}

Penerapan prinsip perlindungan keanekaragaman hayati dalam kebijakan perubahan peruntukan, fungsi, dan penggunaan kawasan 
hutan, sama halnya dengan prinsip kehatihatian, yaitu belum diterapkan dengan sepenuhnya, karena pada kenyataannya dalam kebijakan perubahan kawasan hutan, dapat juga dilakukan pada kawasan konservasi. Padahal apabila memperhatikan ketentuan Undang-undang Nomor 5 tahun 1990 tentang Konservasi Sumber Daya Alam Hayati dan Ekosistemnya, dan ketentuan Keputusan Presiden Nomor: 32 Tahun 1990 tentang Pengelolaan Kawasan Lindung, Undang-undang Nomor: 5 Tahun 1994 Tentang Pengesahan United Nations Convention On Biological Diversity (Konvensi Perserikatan Bangsa-Bangsa Mengenai Keanekaragaman Hayati), Undang-undang Nomor 21 Tahun 2004 Tentang Pengesahan Cartagena Protocol On Biosafety To The Convention On Biological Diversity (Protokol Cartagena Tentang Keamanan Hayati Atas Konvensi Tentang Keanekaragaman Hayati), sangatlah jelas bahwa ketentuan tersebut sangat mengedepankan prinsip perlindungan keanekaragaman hayati. Namun dalam kenyataan, lazimnya para pengambil keputusan di negeri ini cenderung berpikir sektoral dan parsial, akibatnya luaran dari berbagai kebijakannya pun tidak mempertimbangkan berbagai aspek dan ketentuan terkait, termasuk dalam kebijakan perubahan kawasan hutan. Prinsip perlindungan terhadap keanekaragaman hayati dapat di kesampingkan oleh kepentingan ekonomi jangka pendek. ${ }^{16}$

\section{Prinsip Tindakan Pencegahan (The Principles of Precaution/Prevention Action)}

Penerapan prinsip tindakan pencegahan ini, juga belum terlaksana dengan baik, karena pada kenyataannya dalam kebijakan perubahan kawasan hutan, instrumen pencegahan kerusakan kawasan hutan seperti kajian lingkungan hidup strategis (KLHS), AMDAL, aspek tata ruang, perizinan yang sah, senantiasa di kesampingkan, dalam arti instrumen tersebut tidak dijadikan norma pemerintahan (bestuurnormen) oleh pengambil keputusan. Namun demi-

\footnotetext{
${ }^{16}$ Okid Parama Astirin, "Permasalahan Pengelolaan Keanekaragaman Hayati Di Indonesia", Biodiversitas: Journal of Biological Diversity, Jurusan Biologi Universitas Sebelas Maret, Vol. 1 (1), 2000, hlm. 36-40
}

kian, melihat paradigma kebijakan Kementerian Kehutanan saat ini, ada kecenderungan terjadi perubahan ke arah untuk menerapkan prinsip pencegahan. Hal ini terlihat dari banyaknya usulan untuk dilakukannya perubahan terhadap kawasan hutan, masih dilakukan pengkajian oleh Tim Terpadu, dan sampai saat ini proses pengkajian dimaksud masih terus berlangsung. Berdasarkan ketentuan Pasal 5 Peraturan Pemerintah Nomor: 10 Tahun 2010 tentang Tata Cara Perubahan Peruntukan dan Fungsi Kawasan Hutan, disebutkan bahwa Menteri Kehutanan hanya dapat memberikan persetujuan dengan berdasarkan hasil kajian dari Tim Terpadu. Ketentuan Pasal 5 ini sebenarnya merupakan salah satu bentuk dari penerapan prinsip pencegahan, namun dalam implementasinya sebelum Peraturan Pemerintah ini dikeluarkan, meski sudah diatur dalam Pasal 19 (1) Undang-undang Nomor: 41 Tahun 1999 tentang Kehutanan, kinerja Tim Terpadu belum di lakukan dengan baik dan difasilitasi sebagaimana mestinya.

\section{Prinsip Internalisasi Biaya Lingkungan (The Principles of Internalization of Environmen- tal Costs)}

Prinsip internalisasi biaya lingkungan mengandung makna bahwa dalam kebijakan perubahan peruntukan, fungsi, dan penggunaan kawasan hutan, harus sudah diperhitungkan kemungkinan timbulnya dampak negatif, baik terhadap kawasan hutan, aspek sosial maupun lingkungan hidup. Oleh karena itu, dalam kebijakan perubahan kawasan hutan dimaksud, ada kewajiban yang harus dipenuhi oleh pelaku usaha atas biaya sosial dan lingkungan hidup, guna mengatasi dampak negatif yang mungkin terjadi. Bagi pengusaha sudah seharusnya memperhitungkan biaya kerusakan hutan atau kawasan hutan yang diusahakannya, agar dalam pemanfaatannya dapat berkelanjutan.

\section{Prinsip Daya Dukung Lingkungan (The Prin- ciples of Environmental Capacity)}

Penerapan prinsip daya dukung lingkungan dalam kebijakan perubahan peruntukan, fungsi, dan penggunaan kawasan hutan selama 
ini belum sepenuhnya diterapkan. Hal ini terlihat dari belum dijadikannya AMDAL sebagai syarat dalam mengeluarkan perizinan di bidang kehutanan, padahal AMDAL wajib dilakukan terhadap setiap kegiatan yang diperkirakan mempunyai dampak besar dan penting terhadap lingkungan. Apabila dari kajian AMDAL menunjukkan hasil yang positip, izin kegiatan dapat diberikan, itupun setelah persyaratan lainnya yang ditentukan oleh peraturan perundangan dipenuhi. Pada kenyataannya, perizinan yang terkait dengan pemanfaatan kawasan hutan telah dikeluarkan, bahkan kegiatan operasional telah berlangsung, tanpa dilakukan studi AMDAL terlebih dahulu atau dilakukan studi AMDAL setelah kegiatan berjalan. Dengan demikian hasil studi AMDAL menjadi kehilangan makna, karena studi AMDAL hanya dianggap formalitas belaka.

Mengingat dampak yang mungkin terjadi sementara keberadaan hutan lindung semakin terbatas, maka proses perubahan peruntukan, fungsi, dan penggunaan kawasan hutan terutama yang memiliki fungsi lindung untuk kegiatan nonkehutanan harus melalui tahapan yang ketat dengan berbagai pertimbangan dan melibatkan berbagai kepentingan stakeholder. Perlu dipertimbangkan juga suatu bentuk pengelolaan hutan lindung tanpa harus mengubah fungsi hutan tersebut. Saat ini terbuka kesempatan Carbon Trading melalui mekanisme pembangunan bersih, clean development mechanism (CDM) berdasarkan Protokol Kyoto pembangunan nasional tetap dapat berlanjut. Sumber pendanaan pembangunan dari perdagangan karbon ini memberikan peluang menjual hutan tanpa menebang pohon, sehingga pembangunan dapat berkelanjutan dan amanat generasi mendatang untuk mewariskan sumber daya hutan lestari dapat terwujud.

\section{Prinsip Keutuhan (The Principles of Whole- ness/Holistic)}

Prinsip keutuhan ini juga belum diterapkan sepenuhnya dalam kebijakan perubahan peruntukan, fungsi, dan penggunaan kawasan hutan. Hal ini terlihat dari kebijakan yang tidak mempertimbangkan seluruh aspek kepentingan terkait, karena keputusan cenderung diputuskan secara sepihak, tanpa melihat aspek biofisik lingkungan, sosial dan budaya masyarakat. Prinsip keutuhan terkait dengan perubahan kawasan hutan ini seharusnya tercermin dalam skala analisis yang meliputi kebun, tambang, ekosistem, ekoregion, para pemangku kepentingan, dan kebijakan yang dibutuhkan dalam memahami aspek kesejahteraan masyarakat, konservasi, keadilan, dan dampak potensial dari aktivitas manusia. Dalam prinsip keutuhan ini haruslah mengutamakan harmoni dari konservasi, keadilan dan kesejahteraan masyarakat. Interdependensi di antara ketiga aspek tersebut harus di ekspresikan dalam perencanaan, pelaksanaan, monitoring, evaluasi dan refleksi pengelolaan kawasan hutan.

\section{Prinsip Keterpaduan (The Principles of Inte- gration)}

Prinsip keterpaduan dalam implementasinya ini belum diterapkan baik pada lintas sektor di tingkat pusat maupun lintas dinas/instansi di daerah. Dalam pelaksanaan kebijakan perubahan peruntukan, fungsi, dan penggunaan kawasan hutan selama ini belum ada keterpaduan, baik dalam perencanaan, pelaksanaan, pengawasan maupun dalam evaluasinya. Kebijakan perubahan peruntukan, fungsi, dan penggunaan kawasan hutan, sangat tergantung kepada pihak yang menginginkannya, yang terjadi selama ini yaitu untuk memenuhi kepentingan dari pihak dunia usaha, dengan beragam kegiatan usahanya. Pemerintah, baik pusat mau pun daerah terkesan merasa sangat "senang," bila ada investor yang ingin membuka usaha perkebunan ataupun pertambangan, sehingga berapapun luas kawasan hutan yang diinginkan cenderung akan dipenuhi, bahkan sekalipun areal yang diinginkan berada pada kawasan lindung atau kawasan konservasi. Hal ini terjadi karena pemerintah berpikir ada investor berarti ada uang masuk bagi kas negara atau kas daerah, tanpa berpikir lebih jauh dengan memper- 
timbangkan dampak negatif dari aspek sosial dan lingkungan hidup yang akan terjadi. ${ }^{17}$

Selain itu, kebijakan perubahan peruntukan, fungsi, dan penggunaan kawasan hutan selama ini tidak terencana dengan baik, akibatnya sulit untuk diketahui sudah berapa banyak luasan kawasan hutan dan pada kawasan hutan apa saja, serta berapa lagi luasan suatu kawasan hutan yang tersisa, setelah dilakukan tukar-menukar, pelepasan, ataupun pinjam pakai tidak dapat diketahui secara pasti, bahkan tidak jarang terjadi tumpang tindih, seharusnya kebijakan perubahan dilakukan pada kawasan hutan produksi, ternyata justru masuk dalam wilayah kawasan hutan lindung atau kawasan hutan konservasi.

\section{Prinsip Keseimbangan (The Principles of $\mathrm{Ba}$ - lances)}

Prinsip keseimbangan ini dalam implementasinya belum ditransformasikan dalam kebijakan perubahan peruntukan, fungi, dan penggunaan kawasan hutan. Hal ini dapat dicermati dari kerusakan kawasan hutan yang terjadi selama ini. Akar permasalahan dari kerusakan kawasan hutan tersebut yaitu karena adanya ketidakseimbangan dalam pemanfaatan ketiga fungsi di atas. Faktor ekonomi menjadi faktor paling mendominasi pengelolaan hutan bahkan terkadang tanpa menghiraukan kedua faktor lainnya yaitu sosial budaya dan lingkungan hidup. Konsep pemanfaatan hutan seimbang dan dinamis tidak dijalankan sebagaimana mestinya. Seimbang dapat diartikan bahwa dalam pengelolaan kawasan hutan, ketiga fungsi memainkan peranannya dengan tidak mengganggu fungsi masing-masing. Dinamis mengacu kepada sebuah pertumbuhan atau gerakan ke arah perubahan positif. ${ }^{18}$ Namun pada kenyataannya bukan konsep dinamis yang diperjuangkan, pengelolaan kawasan hutan sepertinya jalan di

\footnotetext{
${ }^{17}$ Lihatl Wayan Parsa, "Beberapa Kendala Dalam Penegakan Hukum Lingkungan", Majalah IImu Hukum Kertha Patrika, Fakultas Hukum Universitas Udayana, Vol. 21 (67), 1997, hlm. 23-27

${ }^{18}$ Lihat mengenai filosofi penegakan hukum lingkungan dalam Ferdi, "Peranan Filsafat Hukum Dalam Penegakan Hukum Lingkungan Indonesia", J urnal IImu Pengetahuan Dan Teknologi Universitas 17 Agustus 1945 J akarta, Vol. 6 (2), 2002, hlm. 55-57
}

tempat (statis) bahkan menunjukkan perubahan ke arah negatif. Data menunjukkan bahwa laju deforestasi (kerusakan hutan alam) mencapai lebih dari 2 juta ha per tahun.

\section{Prinsip Jaminan Kepastian Hukum terhadap Status Kawasan Hutan (The Principles of Le- gal Certainty over the Status of Forest Areas)}

Suatu kawasan hutan yang telah ditetapkan status hukumnya sebagai kawasan dengan fungsi utamanya fungsi lindung, fungsi konservasi, dan fungsi produksi, maka harus tetap dipertahankan status hukum dari fungsi dimaksud. Setelah ditetapkan status hukumnya sebagai suatu kawasan hutan tertentu, tidak lagi dengan mudah mengubah status tersebut setiap saat dengan berbagai alasan. Kepastian hukum atas status kawasan hutan ini penting, karena dengan status hukum yang pasti akan menjadi instrumen utama dalam proses perlindungan dan pengelolaan suatu kawasan hutan. Tanpa adanya kepastian hukum atas suatu kawasan hutan, maka akan berdampak pada lemahnya perlindungan dan termasuk dalam pengelolaan suatu kawasan hutan. ${ }^{19}$ Fakta di lapangan ternyata banyak kawasan hutan yang dimanfaatkan tidak sesuai dengan statusnya, sehingga kondisi tersebut mendorong pemerintah daerah untuk menyetujui usulan alih fungsi kawasan hutan.

\section{Prinsip Penegakan Hukum, Baik Preventif maupun Represif secara Tegas dan Konsisten (The Principles of Prevention and Law Enfor- cement, both Preventive and Repressive Firmly and Consistently)}

Pada kenyataannya, prinsip ini belum diterapkan dalam kebijakan perubahan peruntukan, fungsi, dan penggunaan kawasan hutan selama ini. Penegakan hukum preventif baik berupa penerapan ketentuan persyaratan yang telah ditetapkan oleh peraturan peundang-undangan dalam proses perizinan seringkali dila-

\footnotetext{
${ }^{19}$ Lihat Sudi Fahmi, "Problematika Hukum dalam bidang kehutanan", Jurnal Respublica, Fakultas Hukum Universitas Lancang Kuning Pekanbaru, Vol. 6 (1), 2006, hlm. 46-55
} 
laikan oleh pengambil keputusan dan pelaku usaha. Demikian juga pengawasan dan evaluasi pasca pemberian izin, hampir tidak pernah dilakukan secara optimal oleh pemerintah dengan berbagai alasan yang dianggap sebagai kendala baik teknis maupun administratif. Penegakan hukum represif juga tidak optimal ditegakkan, sehingga pelanggaran dan penyimpangan di lapangan terus terjadi tanpa dapat dihentikan, juga dengan berbagai alasan, yang pada intinya hukum administrasi dan atau hukum pidana lingkungan tidak dapat ditegakkan.

\section{Perspektif Pengembangan Prinsip Hukum Pe- lestarian Fungsi Lingkungan Hidup sebagai Asas Umum dalam Kebijakan Pengelolaan Ka- wasan Hutan Berkelanjutan}

Ketigabelas prinsip tersebut di atas, ternyata belum dapat menjadi instrumen pencegahan kerusakan kawasan hutan. Kondisi ini menurut penulis disebabkan oleh beberapa hal. Pertama, prinsip hukum pelestarian fungsi lingkungan hidup sebagaimana teraktualisasikan dalam berbagai regulasi yang terkait dengan bidang kehutanan belum dijadikan acuan dalam penetapan kebijakan perubahan peruntukan, fungsi dan penggunaan kawasan hutan; kedua, para pengambil keputusan ada kecenderungan tidak mengindahkan regulasi yang ada dalam penetapan perubahan peruntukan, fungsi dan penggunaan kawasan hutan; ketiga, para pengambil keputusan cenderung tidak memahami peraturan perundang-undangan kehutanan dan peraturan yang terkait bidang kehutanan dengan baik, akibatnya makna filosofi yang terkandung dari konsiderans "menimbang" suatu peraturan tidak teraktualisasikan dalam penetapan suatu kebijakan dan atau pemberian suatu keputusan izin; keempat, penetapan perubahan peruntukan, fungsi dan penggunaan kawasan hutan, dilakukan oleh pejabat yang tidak memiliki kewenangan (gubernur/bupati/walikota/ kepala dinas); atau terdapat pelanggaran kewenangan; kelima, penetapan kebijakan perubahan peruntukan, fungsi dan penggunaan kawasan hutan, dilakukan tidak sesuai dengan prosedur yang benar dan objektif, misalnya dalam hal KLHS, AMDAL; keenam, penetapan pe- rubahan peruntukan, fungsi dan penggunaan kawasan hutan, dilakukan tidak sesuai dengan substansi dari perubahan kawasan hutan, misalnya terhadap kawasan hutan yang sudah jelas mempunyai fungsi lindung dan berdasarkan ketentuan yang berlaku tidak diperbolehkan di ubah peruntukan, fungsi, dan penggunaannya, namun tetap diberikan izin pemanfaatannya.

Untuk itu menurut penulis perlu dikembangkan prinsip pelestarian fungsi lingkungan hidup lainnya, ${ }^{20}$ yang lebih memiliki sifat memaksa dalam penaatan dan penegakan hukum lingkungan. Prinsip pelestarian fungsi lingkungan hidup dimaksud sebagai asas umum (general principles) diharapkan dapat mengubah pola pikir (mindset) dan menjadi paradigma serta menjadi doktrin yang diaktualisasikan baik dalam rangka pengaturan maupun dalam penetapan kebijakan pengelolaan kawasan hutan ke depan (ius constituendum), dengan pemaknaan yang lebih luas untuk menumbuh kembangkan kembali nilai kebangsaan, sekaligus sebagai upaya membangun karakter (character building) bangsa dalam setiap pengambilan keputusan pembangunan, termasuk dalam pengelolaan kawasan hutan. Ada 4 (empat) prinsip pelestarian fungsi lingkungan hidup yang menurut penulis patut dikembangkan sebagai asas umum (general principles) ke depan (ius constituendum). Pertama, prinsip perusak hutan membayar (the destroyer forest pays principles); kedua, prinsip tanggungjawab negara, peme-

\footnotetext{
${ }^{20}$ Mochtar Kusumaatmadja menyatakan bahwa ketertiban dan keteraturan dalam usaha pembangunan dan pembaharuan memang diinginkan, bahkan mutlak perlu, dan hukum dalam arti norma diharapkan dapat mengarahkan kegiatan manusia kearah yang dikehendaki oleh pembangunan dan pembaharuan. Oleh karena itu, maka diperlukan sarana berupa peraturan hukum yang berbentuk tidak tertulis (prinsip atau asas umum) yang sesuai dengan hukum yang hidup dalam masyarakat. Lihat: Mochtar Kusumaatmadja, 2002, Konsep-konsep Hukum Dalam Pembangunan, Bandung: Alumni, hlm. 88. Selain itu, bila dikaji lebih jauh, Teori hukum pembangunan memakai kerangka acuan pada pandangan hidup (way of live) masyarakat serta bangsa Indonesia berdasarkan asas Pancasila yang bersifat kekeluargaan, maka terhadap asas atau prinsip, lembaga dan norma atau kaidah, relatif sudah merupakan dimensi yang meliputi structure (struktur), culture (kultur) dan substance (substansi). Lihat: Lawrence W. Friedman, 1984, American Law: An invaluable guide to the many faces of the law, and how it affects our daily our daily lives, New York: W.W. Norton \& Company, hlm. 1-8.
} 
rintah, dunia usaha, masyarakat, dan individu (the principles of state responsibility, governments, businesses, communities and individuals); ketiga, prinsip Wawasan Kebangsaan dan Ketahanan Nasional (the principles of nationality and national defense insights); keempat, prinsip kedamaian dalam kehidupan bermasyarakat, berbangsa, dan bernegara (the principles of peace in the life of society, nation, and state). Masing-masing dari keempat prinsip sebagai asas umum tersebut dapat dideskripsikan di bawah ini.

\section{Prinsip Perusak Hutan Membayar (The Des- troyer Forest Pays Principles)}

Prinsip ini mengandung makna bahwa dalam hal kebijakan perubahan peruntukan, fungsi dan penggunaan kawasan hutan menimbulkan dampak negatif yang membahayakan dan atau menimbulkan kerugian bagi kehidupan mahluk hidup dan lingkungan hidup, maka kepada para pelaku dalam pengelolaan dan pengusahaan kawasan hutan, dapat dikenakan kewajiban untuk membayar atas setiap kerugian dan kerusakan yang ditimbulkan. Kewajiban membayar kerugian akibat kerusakan hutan, baik sebagai akibat dari suatu kebijakan pengelolaan kawasan hutan termasuk kebijakan perubahan kawasan hutan, maupun sebagai akibat dari pengusahaan hutan yang tidak mempertimbangkan nilai etika, moral dan norma atau kaidah hukum yang berlaku di bidang pengelolaan sumber daya alam dan lingkungan hidup.

Selain itu, the destroyer pays principles ini, menurut penulis juga dapat diterapkan pada setiap hasil produk yang menggunakan bahan baku dari hasil hutan alam terutama kayu. Paling tidak ada dua sasaran yang dituju, yaitu: pertama, bagi pengusaha atau produsen yang memperoleh izin pemanfaatan hasil hutan alam kayu, akan ekstra hati-hati dan tidak bersifat eksploitatif dalam pemanfaatan hasil hutan alam kayu. Semakin besar jumlah hasil kayu yang dimanfaatkan/dipanen, maka akan semakin besar pula kemungkinan dampak kerusakan yang akan terjadi, dan oleh karenanya dapat dikenakan kewajiban membayar yang lebih besar, begitu pula sebaliknya. Kedua, ba- gi konsumen, terutama yang memperoleh manfaat secara langsung dari hasil kayu hutan alam dan atau hasil produksi dari kayu yang berasal dari hutan alam, dapat juga dikenakan kewajiban membayar, karena sudah ikut andil di dalam faktor penyebab kerusakan hutan dan atau kawasan hutan yaitu tingginya permintaan terhadap produksi hasil hutan akan mendorong produsen untuk memperbesar kapasitas produksinya.

Penerapan prinsip the destroyer pays principles ini, dapat dipastikan akan ditentang baik oleh pengusaha/ produsen maupun konsumen. Tetapi apabila baik pengusaha/produsen maupun konsumen mau menyadari, bahwa sebenarnya prinsip ini sebagai sebuah konsep mengajak kepada upaya pengelolaan dan pemanfaatan hutan maupun kawasan hutan secara berkelanjutan. Dengan harapan agar hutan dan kawasan hutan dengan segala fungsinya tidak hanya dapat dinikmati manfaatnya oleh generasi saat ini tapi juga bagi generasi yang akan datang, termasuk kemungkinan musibah dan bencana yang akan timbul dari kerusakan yang terjadi. Masyarakat pengusaha dan masyarakat pengguna haruslah memiliki kearifan (wisdom) dan rasa prihatin atas kerusakan hutan dan kawasan hutan, serta rasa malu untuk berprilaku merusak. Sifat arif dibutuhkan untuk memunculkan penaatan terhadap etika, moral, dan norma hukum. Sifat prihatin akan menumbuhkan pengendalian diri, sehingga tidak bertindak mengikuti keinginan dan nafsu semata. Sifat malu akan menumbuhkan tanggungjawab atas setiap perbuatan pelanggaran dan penyimpangan yang dilakukan.

Memang tidak mudah di dalam menghitung tingkat kerugian yang ditimbulkan akibat dari suatu kerusakan kawasan hutan yang harus dibayar oleh pelaku perusakan, karena akan sangat tergantung berapa luasan kawasan hutan yang rusak, seberapa besar dampak negatif yang ditimbulkan baik secara materil maupun imateril (social and culture cost), kemudian menetapkan biaya penanggulangan dan rehabilitasi kawasan hutan dan lingkungan hidup yang rusak. Namun demikian, meski tidak mudah dalam penghitungannya, bukan berarti ti- 
dak dapat dihitung nilai kerugian tersebut, hanya saja dalam menghitung tingkat kerugian tidak boleh spekulatif dan perkiraan atau estimasi yang terlalu jauh. Apabila dirujuk Protocol Kyoto, penghitungan tingkat kerugian dapat diekuivalenkan dengan seberapa banyak suatu luasan kawasan hutan dapat menyerap gas karbon, dan hal ini dapat dinilai secara nominal, sehingga dapat dikompensasikan atas kerusakan hutan dan atau kawasan hutan yang terjadi, dan hal ini menjadi kewajiban yang harus dibayar oleh perusak hutan atau kawasan hutan.

Menurut penulis penerapan prinsip perusak hutan membayar (the destroyer forest pays principles) dan kriteria sebagai indikator penerapannya cukup mendesak untuk diimplementasikan, mengingat kerusakan hutan dan atau kawasan hutan di Indonesia saat ini sudah sampai pada situasi yang mengkhawatirkan keselamatan manusia Indonesia khususnya dan masyarakat dunia pada umumnya. Untuk itu diharapkan prinsip ini dapat diaktualisasikan dalam regulasi baik di tingkat pusat maupun daerah, sehingga dapat menjadi norma hukum positip yang memiliki kekuatan berlaku dan memaksa bagi pihak yang dituju oleh ketentuan ini.

Prinsip Tanggungjawab Negara, Pemerintah, Dunia Usaha, Masyarakat, dan Individu (The Principles of State Responsibility, Governments, Businesses, Communities and Individuals)

Prinsip ini patut untuk dikembangkan mengingat dalam pengelolaan kawasan hutan saat ini, rasa tanggungjawab dari seluruh komponen bangsa (negara, pemerintah, dunia usaha, masyarakat, dan individu), nampak mulai luntur dan terdegradasi oleh berbagai kepentingan yang bersifat pragmatis, kepentingan ekonomi sesaat, kepentingan kelompok dan individu. Tanggung jawab untuk menjaga keberlanjutan dari kawasan hutan sangat rendah. Negara telah menyerahkan pengelolaan sumber daya alam termasuk hutan kepada pemerintah. Kebijakan Pemerintah dalam pengelolaan potensi sumber daya alam termasuk hutan dilakukan secara optimal agar dapat menghasilkan sumber perdanaan bagi pembangunan. Kondisi dunia usaha yang ada selama ini lebih berorientasi pada keuntungan yang sebesar-besarnya bagi kepentingan pemilik perusahaan dan kelompoknya. Masyarakat dan individu juga seakan tidak mau ketinggalan untuk ikut serta mengambil bagiannya, yaitu dengan ikut membuka dan merambah kawasan hutan, baik dengan izin ataupun tanpa izin.

Untuk itu, menurut penulis sangat perlu dikembangkan prinsip tanggung jawab ini, agar dapat dilakukan reorientasi kembali terhadap sikap tanggung jawab para pengambil keputusan selama ini. Prinsip ini mengandung makna bahwa semua pihak yaitu negara, pemerintah, dunia usaha, masyarakat, dan individu, harus memiliki rasa tanggung jawab dalam melindungi dan mengelola kawasan hutan. Terlebih lagi dalam kebijakan perubahan kawasan hutan, meskipun negara dan pemerintah memiliki kewenangan untuk mengubah peruntukan, fungsi, dan penggunaan kawasan hutan, tidak berarti dalam pelaksanaan kewenangan tersebut dapat dilakukan semena-mena, tanpa mengindahkan prinsip hukum pelestarian fungsi lingkungan hidup. Demikian pula dunia usaha, masyarakat dan individu, yang diberi hak untuk mendapatkan manfaat dari suatu kawasan hutan, harus bertanggungjawab untuk melindungi dan mengelolanya dengan baik, yaitu dengan memperhatikan nilai etika, moral, norma atau kaidah hukum yang berlaku. Tanggung jawab yang dimaksudkan dalam prinsip ini, termasuk upaya penanggulangan dan rehabilitasi yang harus dilakukan, manakala terjadi dampak negatif berupa kerusakan kawasan hutan dan bencana lingkungan yang terjadi sebagai akibat dari kebijakan dan atau pemanfaatannya.

\section{Prinsip Wawasan Kebangsaan dan Ketahanan Nasional (The Principles of Nationality and National Defense Insights)}

Konsep wawasan kebangsaan (nusantara) dan ketahanan nasional ini, kiranya relevan apabila diaktualisasikan di dalam pengambilan kebijakan dan atau keputusan apakah suatu kawasan hutan dapat dilakukan perubahan peruntukan, perubahan fungsi, dan atau penggu- 
naannya (pinjam pakai) atau tidak. Artinya para pengambil keputusan harus memiliki wawasan kebangsaan dan ketahanan nasional, sehingga dalam pengambilan suatu keputusan dan atau tidak mengambil suatu keputusan didasarkan atas atau mempertimbangkan kepentingan bangsa, bukan atas kepentingan pribadi atau pun kelompok, apalagi atas kepentingan pribadi dari pejabat pengambil keputusan. Oleh karena itu menurut penulis, prinsip ini sangat penting dan harus menjadi landasan dalam setiap pengambilan keputusan oleh setiap pemimpin di Republik ini.

Prinsip ini mengandung makna bahwa dasar pemikiran wawasan kebangsaan dapat ditinjau berdasarkan falsafah Pancasila, aspek kewilayahan nusantara, aspek sosial budaya bangsa Indonesia, dan aspek kesejarahan, sehingga wawasan kebangsaan menjadi landasan visional bangsa Indonesia, dalam rangka mewujudkan masyarakat Indonesia yang adil dan makmur berdasarkan Pancasila. ${ }^{21}$ Keadilan dan kemakmuran tersebut diupayakan perwujudannya melalui pembangunan di berbagai bidang, yaitu dengan mengelola potensi sumber daya alam yang dimiliki secara arif dan bijak, termasuk kebijakan dalam mengelola kawasan hutan. Oleh karena wawasan kebangsaan merupakan wawasan nasional, maka setiap kebijakan dalam pengelolaan kawasan hutan harus dilandasi oleh faham wawasan kebangsaan.

Mengadopsi pemikiran Talcott Parsons ${ }^{22}$ mengenai teori sistem, wawasan kebangsaan dapat dipandang sebagai suatu falsafah hidup yang berada pada tataran sub-sistem budaya. Dalam tataran ini wawasan kebangsaan dipandang sebagai 'way of life' atau merupakan kerangka/ peta pengetahuan yang mendorong terwujudnya tingkah laku dan digunakan sebagai acuan bagi seseorang untuk menghadapi

\footnotetext{
${ }^{21}$ Wawasan kebangsaan merupakan jiwa, cita-cita, atau falsafah hidup yang tidak lahir dengan sendirinya, yang merupakan hasil konstruksi dari realitas sosial dan politik (socially and politically constructed), Bennedict Anderson, Imagined Community: reflections on the Origin and Spread of Nationalism, dalam Otho H. Hadi, Nation and Character Building Melalui Pemahaman Wawasan Kebangsaan, Bappenas, tt., hlm. 2.

22 Parsons, Talcott. Toward a General Theory of Action, dalam Otho H. Hadi, ibid., hlm. 5.
}

dan menginterpretasi lingkungannya. Jelaslah, bahwa wawasan kebangsaan tumbuh sesuai pengalaman yang dialami oleh seseorang, dan pengalaman merupakan akumulasi dari proses tataran sistem lainnya, yakni sub-sistem sosial, sub-sistem ekonomi, dan sub-sistem politik. Pada tataran sub-sistem sosial berlangsung suatu proses interaksi sosial yang menghasilkan kohesi sosial yang kuat, hubungan antar individu, antar kelompok dalam masyarakat yang harmonis. Integrasi dalam sistem sosial yang terjadi sangat mewarnai dan mempengaruhi bagaimana sistem budaya (ideologi/falsafah/pandanngan hidup) dapat bekerja dengan semestinya.

Sub-sistem ekonomi dan sub-sistem politik mempunyai kaitan yang sangat erat. Ada yang mengatakan bahwa paham kebangsaan Indonesia tidak menempatkan bangsa Indonesia di atas bangsa lain, tetapi menghargai harkat dan martabat kemanusiaan serta hak dan kewajiban manusia. Paham kebangsaan berakar pada asas kedaulatan yang berada di tangan rakyat. Oleh karena itu, paham kebangsaan sesungguhnya merupakan paham demokrasi yang memiliki cita-cita keadilan sosial, bersumber pada rasa keadilan dan menghendaki kesejahteraan bagi seluruh rakyat.

Konsepsi ketahanan nasional Indonesia merupakan konsepsi pengembangan kekuatan nasional melalui pengaturan dan penyelenggaraan kesejahteraan dan keamanan yang seimbang, serasi dan selaras dalam seluruh aspek kehidupan secara utuh dan menyeluruh dan terpadu berdasarkan Pancasila, UUD 1945 dan Wawasan Kebangsaan. Dengan kata lain, konsepsi ketahanan nasional merupakan pedoman (sarana) untuk meningkatkan (metode) keuletan dan ketangguhan bangsa yang mengandung kemampuan mengembangkan kekuatan nasional dengan pendekatan kesejahteraan dan keamanan. Kesejahteraan digambarkan sebagai kemampuan bangsa dalam menumbuhkan dan mengembangkan nilai nasionalnya demi kemakmuran yang adil dan merata, rohaniah dan jasmaniah. Keamanan digambarkan sebagai kemampuan bangsa dalam melindungi nilai nasionalnya terhadap ancaman baik dari dalam maupun dari luar negeri. Dalam konteks pengelolaan kawas- 
an hutan, pendekatan kesejahteraan dan keamanan sangatlah relevan untuk diterapkan. Artinya kebijakan perubahan kawasan hutan, harus mengantarkan rakyat Indonesia kepada kesejahteraan dan terhindar dari berbagai ancaman dan hambatan dari pihak yang hanya akan mengambil manfaat dari potensi kekayaan sumber daya hutan Indonesia. ${ }^{\mathbf{2 3}}$

\section{Prinsip Kedamaian dalam Kehidupan Ber- masyarakat, Berbangsa, dan Bernegara (The Principles of Peace in the Life of Society, Nation, and State)}

Prinsip ini terkandung makna bahwa dalam kebijakan perubahan peruntukan, fungsi dan penggunaan kawasan hutan harus dihindari kemungkinan timbulnya konflik, baik konflik secara vertikal maupun konflik horizontal. Oleh karena itu, sebelum ditetapkannya keputusan tentang perubahan atas suatu kawasan hutan, harus melibatkan pihak berkepentingan yang terkait. Suatu keputusan yang baik dan sah yaitu suatu keputusan yang memenuhi syarat formal dan syarat material. Indikatornya yaitu keputusan tersebut memiliki bentuk hukum yang jelas dan dikeluarkan sesuai dengan kewenangan, prosedur dan substansi dari keputusan tersebut. Apabila syarat formal dan material telah terpenuhi berarti sesuai dengan asas keabsahan (rechmatigheid), maka dapat dihindari terjadinya konflik dalam kebijakan perubahan kawasan hutan. Dengan demikian kedamaian dalam kehidupan bermasyarakat, berbangsa dan bernegara akan dapat terwujud.

Saat ini konflik di sektor kehutanan cukup kompleks, artinya banyak pihak yang terlibat dan terkait. Konflik dapat terjadi antara pihak masyarakat dengan pihak pemerintah (sebagai pengelola kawasan hutan dan hutan), antara pihak masyarakat dengan pihak pengusaha, serta pihak pemerintah dengan pihak pengusaha. Secara umum, konflik ini menggambarkan semrawutnya penataan pemanfaatan kawasan hutan. Secara khusus konflik menggambarkan kon-

\footnotetext{
${ }^{23}$ Lihat Iskandar, 2009, Pendidikan Pancasila dan Kewarganegaraan, Modul, Poltekpos, Bandung, hlm. 28., lihat juga Pengantar Kewarganegaraan, http:// ocw. gunadarma. ac. id/ course.
}

sepsi dan pengelolaan kehutanan yang tidak baik. Artinya, dalam pengelolaan hutan ada ketidakseimbangan keuntungan atau manfaat dari setiap pihak yang terlibat dan terkait. Dalam tataran praktis di lapangan, dapat dilihat dari konsepsi dan praktik pengelolaan yang didasarkan kepentingan "ekonomi-politik" yang dominan. Siapa yang kuat "modal dan kuasa" maka akan dapat mendominasi dan menang.

Salah satu penyebab konflik di bidang kehutanan, yang mendapat perhatian sangat minim yaitu masalah tata batas antara kawasan hutan dan non kawasan hutan. Persoalannya tidak hanya selesai pada tuntasnya pemetaan tata batas hutan, tapi pada penentuan tata batas yang baik sebagaimana dalam peraturan dengan melibatkan berbagai pihak (bukan sepihak). Hal ini guna menghindari terjadinya tumpang tindih klaim dari berbagai pihak. Untuk itu perlu dilakukan kajian yang cukup mendalam mengenai tata batas kawasan hutan dan non kawasan hutan ini. Hasil penataan batas dipublikasikan dengan baik, sehingga mengenai tata batas menjadi pengetahuan publik luas, tidak hanya pengetahuan para pemegang kekuasaan, karena hal ini kecenderungannya akan terjadi penyalah-gunaan wewenang.

Urgensi dari prinsip kedamaian ini menurut penulis sangat relevan dengan tujuan dari kehidupan berbangsa dan bernegara Indonesia, yaitu untuk mencapai masyarakat yang adil dan makmur bagi seluruh rakyat Indonesia. Suatu masyarakat yang adil dan makmur tidak akan pernah terwujud, tanpa adanya kedamaian dalam kehidupan bermasyarakat, berbangsa dan bernegara. Oleh karena itu, apapun kebijakan yang ditetapkan oleh pemerintah, hendaknya prinsip kedamaian harus dijadikan pertimbangan, konflik sekecil apapun yang mungkin timbul dari suatu kebijakan haruslah dihindari, karena kebijakan yang ditetapkan tersebut pada akhirnya juga tidak akan dapat dilaksanakan dengan baik dan lancar.

Masing-masing dari keempat prinsip di atas, memiliki posisi saling ketergantungan dan saling memperkuat secara mendasar di antara pertimbangan perlindungan daya dukung lingkungan dengan kepentingan pembangunan eko- 
nomi dan sosial. Prinsip saling ketergantungan ini yang harus diadopsi dan diterjemahkan dalam tataran praktis dalam kebijakan perubahan kawasan hutan, baik kebijakan tukar-menukar, pelepasan, perubahan fungsi, maupun pinjam pakai kawasan hutan.

\section{Penutup}

\section{Simpulan}

Terdapat tiga belas prinsip hukum pelestarian fungsi lingkungan hidup dalam pengeloIaan kawasan hutan berkelanjutan (General Principles of the Forest Area Sustainable Management), sebagai instrumen pencegahan kerusakan kawasan hutan, yaitu: prinsip keadilan, prinsip akses pada informasi, prinsip partisipasi publik, prinsip kehati-hatian, prinsip perlindungan keanekaragaman hayati, prinsip tindakan pencegahan, prinsip internalisasi biaya lingkungan, prinsip daya dukung lingkungan, prinsip keutuhan, prinsip keterpaduan, prinsip keseimbangan, prinsip jaminan kepastian hukum atas status kawasan hutan, prinsip penanggulangan dan penegakan hukum, baik preventif maupun represif secara tegas dan konsisten. Hampir semua prinsip tidak diterapkan atau tidak dijadikan dasar pertimbangan, baik oleh Kementerian Kehutanan, kementerian sektor terkait, mau pun pemerintah daerah dalam kebijakan perubahan peruntukan, perubahan fungsi, dan penggunaan kawasan hutan selama ini. Tidak diterapkannya prinsip hukum sebagai asas umum (general principles) membuktikan bahwa kebijakan pengelolaan kawasan hutan belum di arahkan bagi kesejahteraan masyarakat dengan sasaran pengelolaan dari aspek sosial budaya, ekonomi, dan pelestarian fungsi lingkungan hidup dalam proporsi yang seimbang.

Perlu dikembangkan (perspektif ius constituendum) prinsip hukum lingkungan sebagai asas umum (general principles), yang lebih memiliki sifat memaksa dan mengarah pada pembangunan karakter kepemimpinan para pengambil keputusan. Prinsip dimaksud yaitu prinsip perusak hutan membayar (the destroyer forest pays principles); prinsip tanggungj awab negara, pemerintah, dunia usaha, masyarakat, dan individu (principles of state responsibility, govern- ments, businesses, communities and individuals); prinsip wawasan kebangsaan dan ketahanan nasional (the principles of nationality and national defense insights); dan prinsip kedamaian dalam kehidupan bermasyarakat, berbangsa, dan bernegara (the principles of peace in the life of society, nation, and state). Keempat prinsip hukum dimaksud sebagai asas umum, diharapkan dapat mengubah mindset para pengambil keputusan, kemudian menjadi paradigma yang diikuti oleh para pemangku kepentingan. Lebih jauh diharapkan prinsip dimaksud dapat menjadi doktrin atau salah satu sumber hukum sebagai solusi untuk mengatasi permasalahan kerusakan kawasan hutan, baik oleh pembentuk undang-undang, pemerintah, aparat penegak hukum, dan pelaku usaha, serta masyarakat pada umumnya.

\section{Daftar Pustaka}

Angga, Dade. "Kemitraan Pemerintah, Masyarakat Dan Swasta Dalam Pembangunan: Suatu Studi Tentang Kasus Kemitraan Sektor Kehutanan Di Kabupaten Pasuruan". Jurnal Aplikasi Manajemen, Vol. 4 (3), 2006. J urusan Manajemen Universitas Brawijaya;

Astirin, Okid Parama. "Permasalahan PengeloIaan Keanekaragaman Hayati Di Indonesia". Biodiversitas: Journal of Biological Diversity, Vol. 1 (1), 2000. Jurusan Biologi Universitas Sebelas Maret;

Fahmi, Sudi. "Problematika Hukum dalam Bidang Kehutanan". J urnal Respublica, Vol. 6 (1), 2006. Fakultas Hukum Universitas Lancang Kuning Pekanbaru;

Ferdi. "Peranan Filsafat Hukum Dalam Penegakan Hukum Lingkungan Indonesia"; Jurnal IImu Pengetahuan dan Teknologi Vol. 6 (2), 2002. J akarta: Universitas 17 Agustus 1945;

Friedman, Lawrence W. 1984. American Law: An Invaluable Guide to the Many Faces of the Law, and How it Affects Our Daily Lives. New York: W.W. Norton \& Company;

Hadi, Otho H. tt. Nation and Character Building Melalui Pemahaman Wawasan Kebangsaan. Bappenas; 
Iskandar. 2009. Pendidikan Pancasila dan Kewarganegaraan. Modul. Bandung: Poltekpos;

2011. Perubahan Peruntukan, Fungsi, dan Penggunaan Kawasan Hutan Ditinjau Dari Prinsip Hukum Pelestarian Fungsi Lingkungan Hidup Dalam Pengelolaan Kawasan Hutan Berkelanjutan. Disertasi. Bandung: Unpad;

Kusumaatmadja, Mochtar. 2002. Konsep-konsep Hukum Dalam Pembangunan. Bandung: Alumni;

Lisdiyono, Edy. "Penyimpangan Kebijakan Alih Fungsi Lahan Dalam Pelestarian Lingkungan Hidup". Majalah IImiah Hukum dan Dinamika Masyarakat, Edisi Oktober 2004. FH Universitas Tujuh Belas Agustus;

Masduki; "Masyarakat Terbuka Dan Kebebasan Mengakses Informasi, Agenda Pemberdayaan Masyarakat Sipil Rezim SBY-Kalla". Majalah IImiah Unisia, Vol. 28 (55), 2005. Yogyakarta: Universitas Islam Indonesia;

Parsa, Wayan. "Beberapa Kendala dalam Penegakan Hukum Lingkungan". Majalah IImu Hukum Kertha Patrika Vol. 21 (67), 1997. Fakultas Hukum Universitas Udayana;
Ridwan. "Memunculkan Karakter Hukum Progresif dari Asas-Asas Umum Pemerintahan Yang Baik Solusi Pencarian dan Penemuan Keadilan Substantive". J urnal Hukum Pro Justitia, Vol. 26 (2), 2008. Fakultas Hukum Universitas Katholik Parahyangan;

Silaen, August P. "Pelestarian Fungsi Hutan dan Lingkungan Hidup Dalam perspektif $\mathrm{Hu}-$ kum Lingkungan". Majalah IImiah Visi Vol. 16 (3), 2008. Universitas HKBP Nomenssen Medan;

Suminar, Jenny Ratna. "Komunikasi dan PerIuasan Partisipasi Publik dalam Pembangunan". Governance: Sinergi Masyarakat, Swasta dan Pemerintah Yang Berkeadilan, Vol. 3 (9) tahun 2007. Pusat Penelitian Kebijakan Publik Dan Pengembangan Wilayah Universitas Padjadjaran;

Ts, Abdul Bari. "Keanekaragaman Hayati Dalam Pembangunan". Duta Rimba: Majalah BuIanan Perum Perhutani Jakarta, Vol/ 2 (197-198), 1996;

Yusuf, Yusdirman. "Hukum Lingkungan Versus Pembangunan Nasional". J urnal Respublica, Vol. 4 (1), 2004. Fakultas Hukum Universitas Lancang Kuning Pekanbaru. 